\title{
RETABLOS SALOMÓNICOS EN PUEBLA
}

Marco Díaz

Conocido el sentido religioso que anima al barroco salomónicol y pese a que todavia nos queda el recurso de estudiar los contratos que codificaron la creación plástica y los panegíricos que la exaltaron, debemos concentrarnos en analizar los rasgos comunes detectados en una área muy específica; la zona oriental del territorio poblano. Antes de referirnos a esas obras consignamos como punto referencial los ejemplos conservados en la ciudad de los ángeles.

La implantación del salomónico en Puebla se debe al empeño del obispo Juan de Palafox quien para llevar a término la catedral acepta el lenguaje del manierismo con que se había proyectado la sede obispal, más en la decoración adopta el lenguaje en plena vigencia, el salomónico con el que se realiza el retablo de los Reyes. El autor de esta obra ha sido bastante discutido, ${ }^{2}$ sin embargo, se ha dicho poco sobre su influjo.

El altar de los Reyes fue transformado en el siglo XIX, lo conocemos en su apariencia original por un grabado de Naoort, en él se percibe su distribución que para Nueva España resultó muy novedosa. La compartimentación es irregular y pesa en ella el gran lienzo de La Inmaculada que como los cuadros complementarios: Adoración de pastores y Adoración de los reyes y los ángeles que llenan las enjutas son todos obras de Pedro García Ferrer. Por el grabado detectamos el uso de foliaciones e imbricaciones entre los diversos componentes arquitectónicos, las columnas salomónicas significadas por el acentuado estrangulamiento logrado con listeles, los capiteles como será común en todos los retablos son corintios. Pese a la innovación que representa este retablo, la presencia de algunos elementos de la tradición artistica anterior son rasgo común a todo el territorio americano.

El altar mayor de la misma catedral era exento y fue realizado en piedras duras por Diego de Carcamo sobre diseños de García Ferrer, sin embargo, sólo conocemos una vaga descripción ${ }^{3}$.

A pesar de su desaparición estas obras debieron ejercer un considerable

\footnotetext{
1 Faustina Torres Ruiz. Estudio sobre la columna salomónica México, 1970 La bibliografía del retablo salomónico en México incluye especialmente incisivo el ar ticulo de Manuel González Galván "Barroco \$alomónico"en Artes de Méxiuo, México, 1970

Elisa Vargas Lugo "Un retablo del siglo XVII" en Conciencla y autenticidad histöricas. México UNAM, 1974 y Heinrich Berlin "Saivador de Ocampoa Mexican Sculptor" The Americas Washington Academy of Franciscan History, 1948, IV, 4 .

${ }^{2}$ El retablo se ha atribuido en su diseño al escultor sevillano Juan Martínez La descripción de Tamariz y Carmona coincide con el grabado que mencionamos. Es interesante hacer notar que este autor sólo se refiere a las salomónicas como tor tuosas sin darle mayor sentido religioso. Antonio Bonet Correa Retablos del sigloXVII en Puebla Madrid 1963. Manuel Romerode Terreros Las artesindustriales en Nueva España. México, Pedro Robredo, 1923,p $96-97$

${ }^{3}$ Manuel Zerón Zapata La puebla de los ángeles en el siglo XVII Crónica de la puebla. México. Patria, 1945.
} 
efecto El obispo Manuel Fernández de Santa Cruz dedicó en su catedral sendos altares a San Francisco de Sales y a Santa Teresa, estructurados con soportes salomónicos y realizados en jaspe, sin embargo ignoramos hasta que punto esos retablos estuvieron conectados estilísticamente con las obras palafoxianas, pues la descripción es muy escueta ${ }^{4}$.

Entre los escasos retablos del último tercio del siglo XVII han llegado hasta nosotros en la ciudad de Puebla; destaca el principal de la iglesia de los dominicos. Construido por Pedro Maldonado entre 1688 y $1690^{5}$. Adquiere movilidad tanto en los planos extremos como por la colocación de los soportes en pares y triadas subrayando la calle central con una mayor anchura y por el movimiento de las cornisas de los dos primeros cuerpos.

El sentido escultórico se manifiesta en la multitud de planos de fondo. La ocupación de todo el espacio de los intercolumnios por los nichos es otro rasgo estilistico avanzado. En los nichos las peanas son caladas y las veneras se contagian de formas ondulantes. El banco se decora con efigies de fundadores de órdenes y en las bases de los soportes aparecen angelillos

La columna salomónica sólo está presente en el primer cuerpo y en su tratamiento se advierte la plena comprensión del lenguaje. En los senos se adosan una guía de carácter vegetal y el capitel es compuesto.

En el resto de los soportes el criterio es distinto, el galibo se conserva y en los fustes se organiza, simétrica un tipo de decoración muy congruente con su tiempo. En el remate hay pilastrás con atlantes rasgo que encontraremos con frecuencia. Detalles decorativos que también habrían de tener trascendencia son las ménsulas adosadas a los trozos de entablamentos, las molduras rizadas y golpes de hojarasca donde se incluyen niños desnudos. La escultura conserva el aplomo clásico y la policromía no parece ser la original sin embargo, constituye un digno complemento a la fábrica arquitectónica tan singular.

Es cuestionable el vínculo del altar exento de la capilla del Rosario con el baldaquino de la catedral construido en los últimos años del siglo XVII y reformado en la centuria siguiente. La planta en cierta manera estática se desplanta de una base ornada con los motivos más evolucionados del barroco: tarjas de líneas mixtas y golpes de hojarasca ${ }^{6}$. Los soportes de alabastros agrupados del registro bajo recubren una compleja estructura.

En el cuerpo superior las columnas se dispusieron con el mismo criterio, aun cuando la estructura es más ligera. Es de especial interés el tratamiento dado a los fustes: los angulares enredan una guía inanimada, especie de cartón o roleo y los centrales se recubren con acentuadas estrías, en ambos casos los capiteles son compuestos, salvo la decoración excavada de las cornisas no

\footnotetext{
4 Manuel Romero de Terreros, Op sit, p. 98

${ }^{5}$ Manuel Toussaint La aledral y las iglesias de puebla. México, Por rúa, p. 113

${ }^{6}$ La conjetura de Antonio Bonet Correa en el artículo citado fue corroborada en la restauración de 1968 consignada por De la Maza en La decoración simbólica del Rosario. Puebla Eds. Altiplano, 1971, p. 46
} 


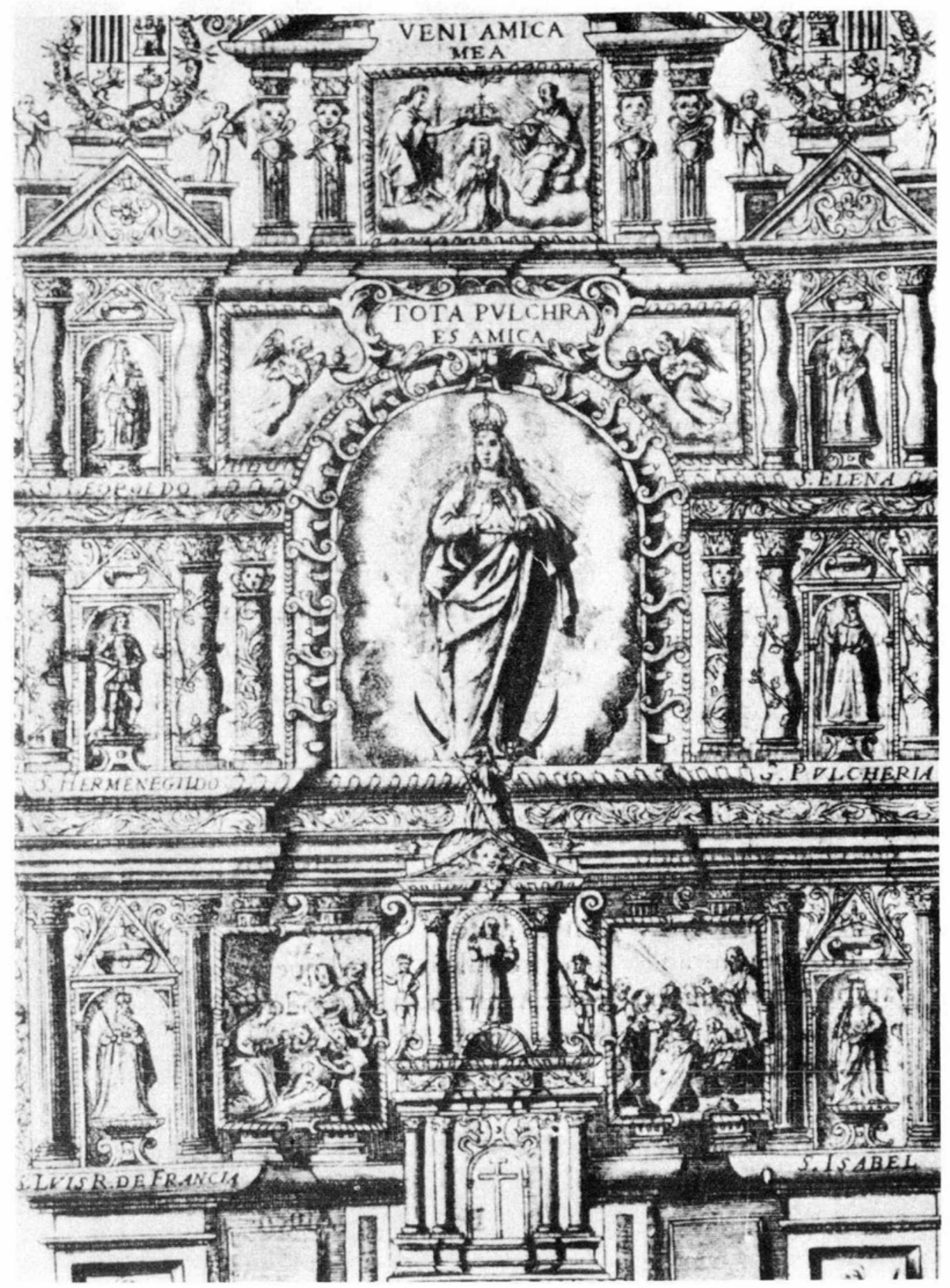

Lámina 1. Puebla. Retablo de los Reyes de Juan de Naoort. 


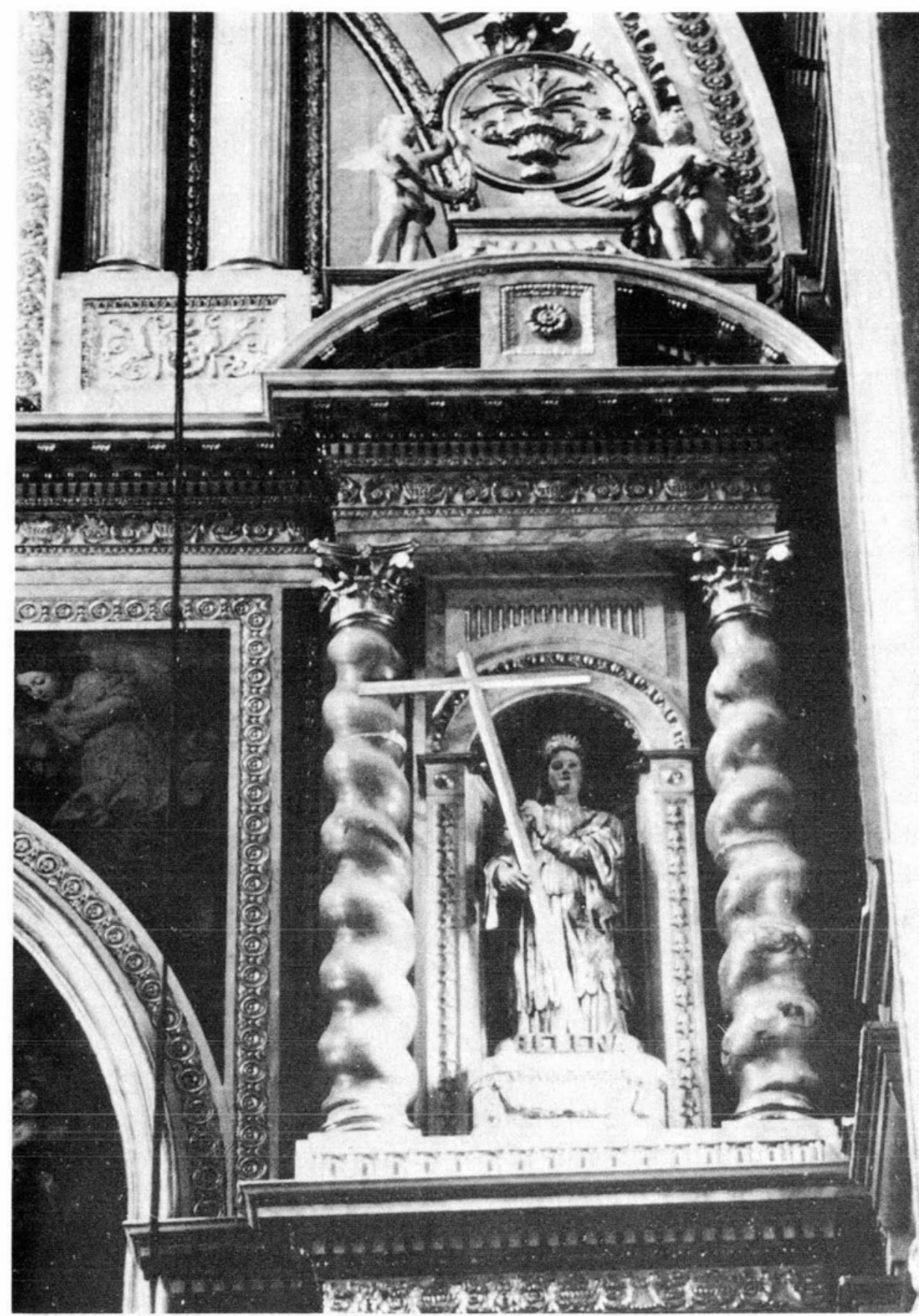

Lámina 2. Puebla. Retablo de los Reyes. 


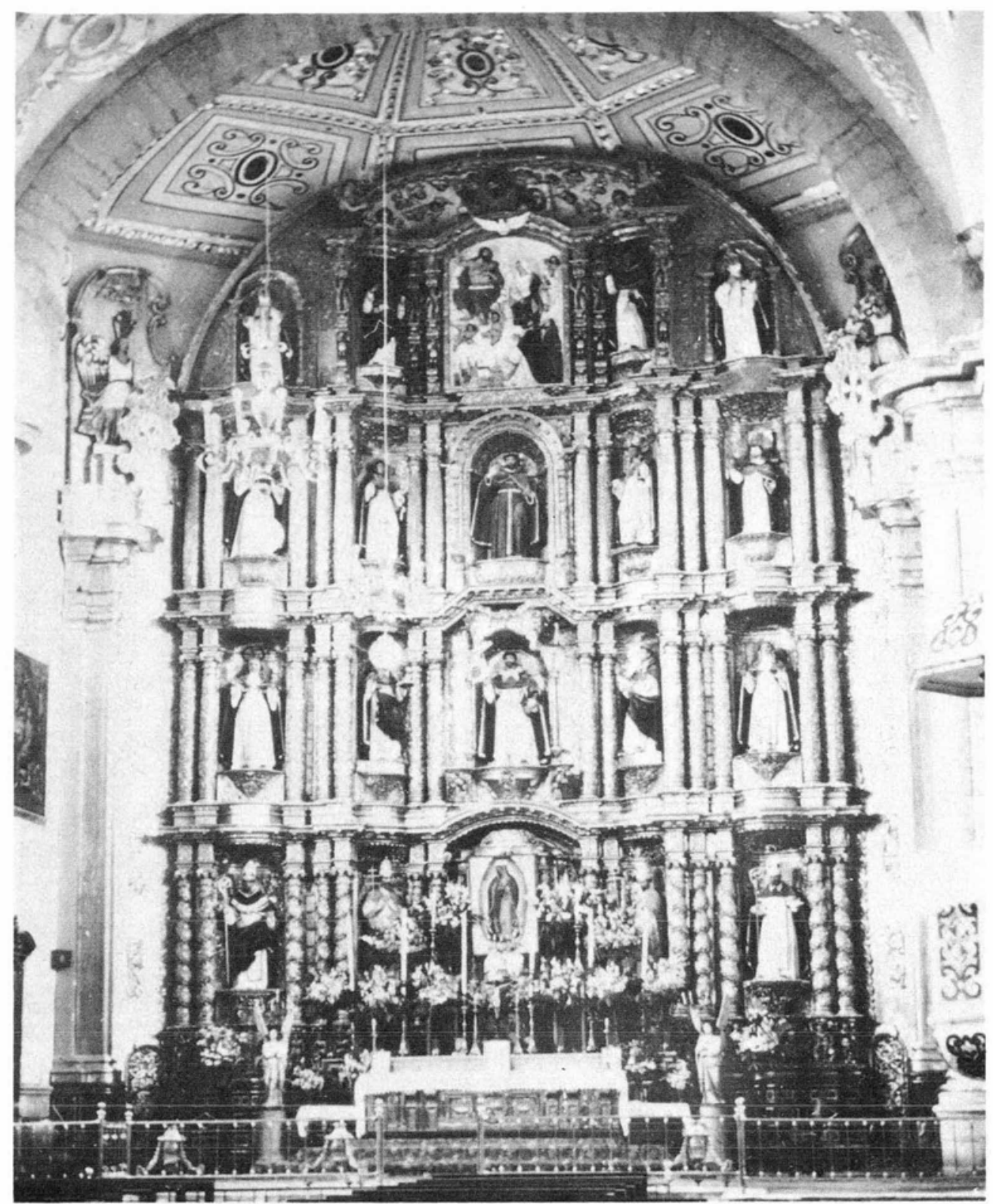

Lámina 3. Puebla, Santo Domingo, Retablo Mayor. 


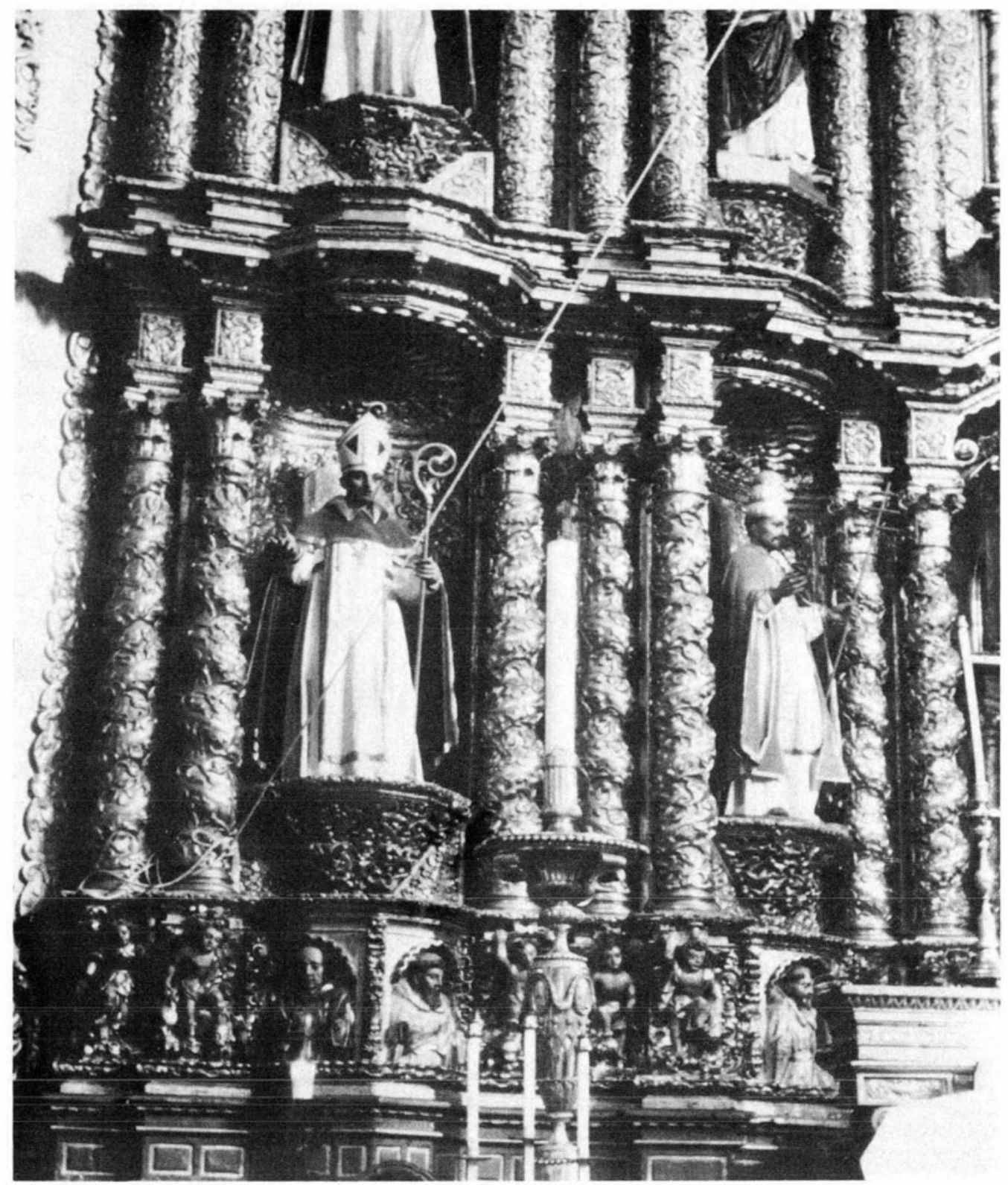

Lámina 4. Puebla, Santo Domingo, Retablo Mayor, detalle. 


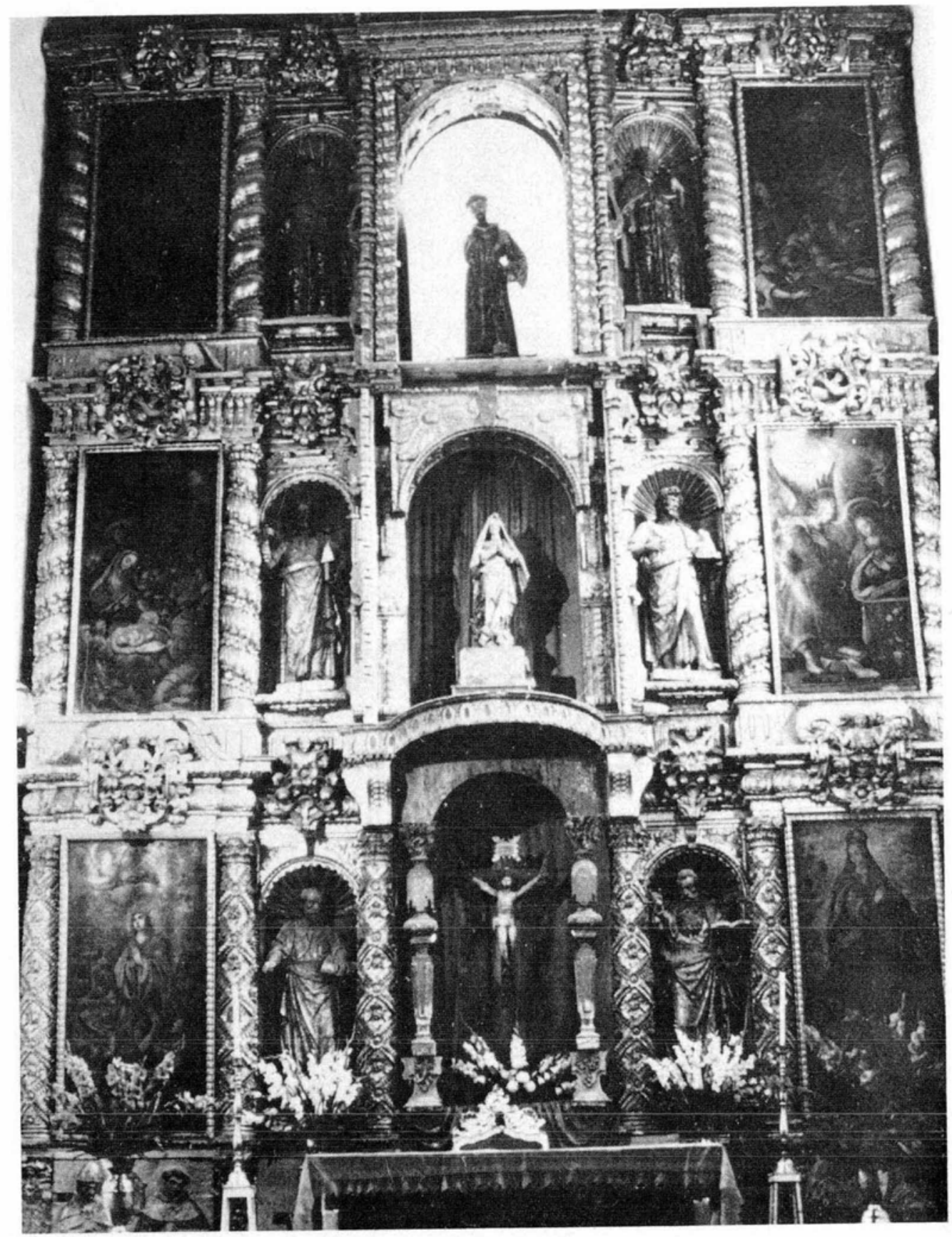

Lámina 5. Tlaxcala, Convento Franciscano. Retablo Mayor. 

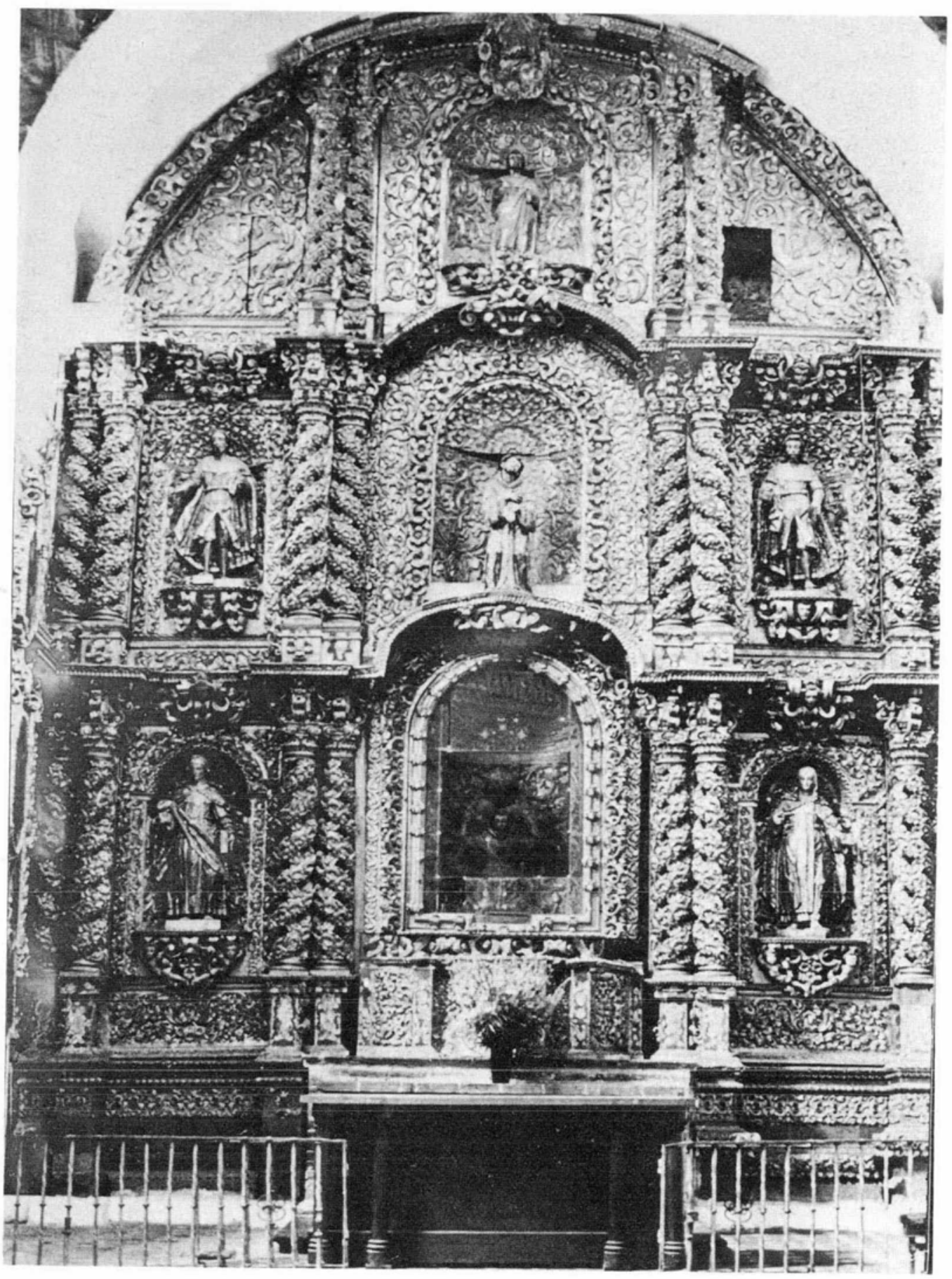

Lámina 6. Tlaxcala, Capilla Tercer Orden. 


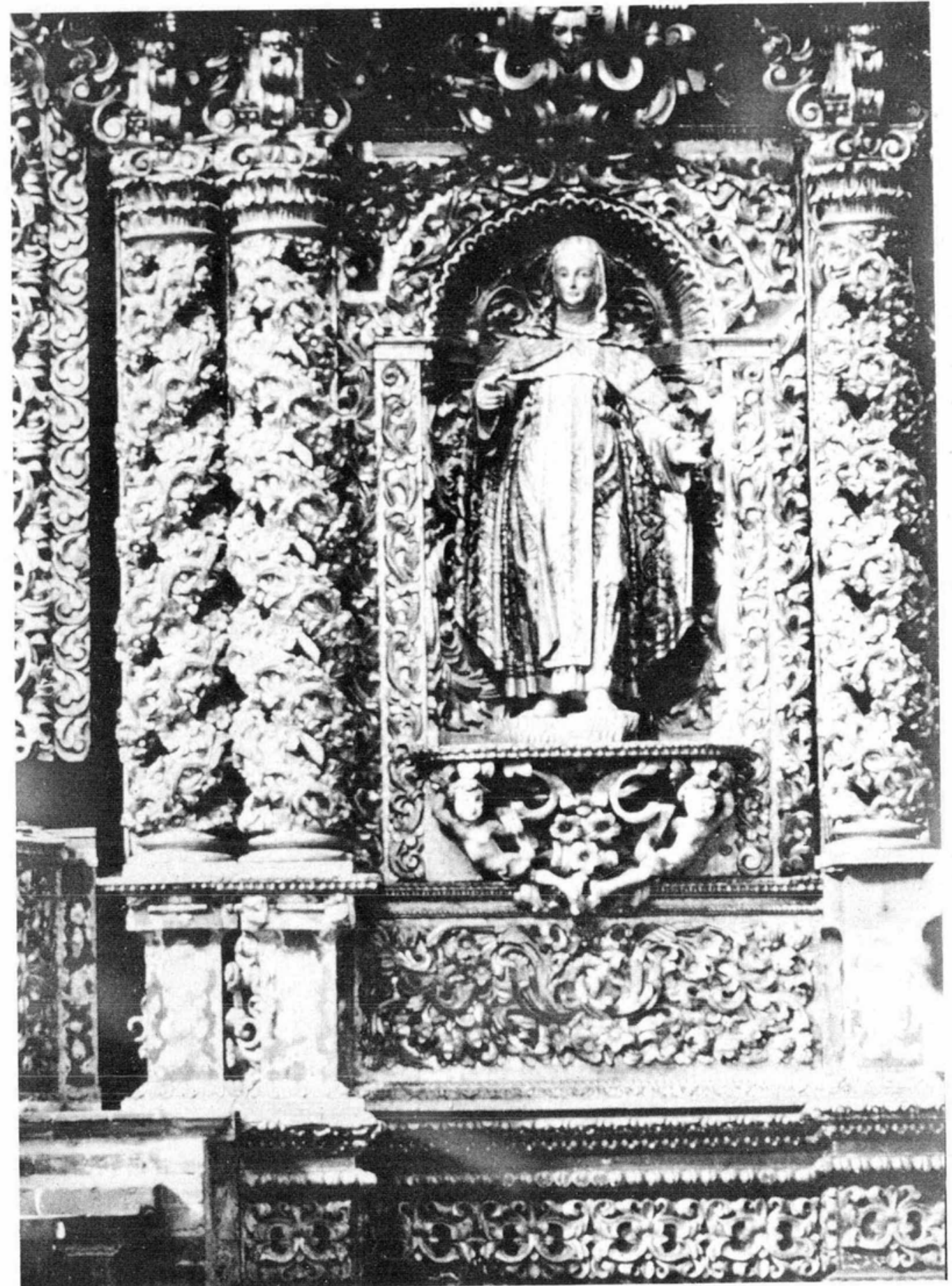

Lámina 7. Tlaxcala, Capilla Tercer Orden, detalle. 


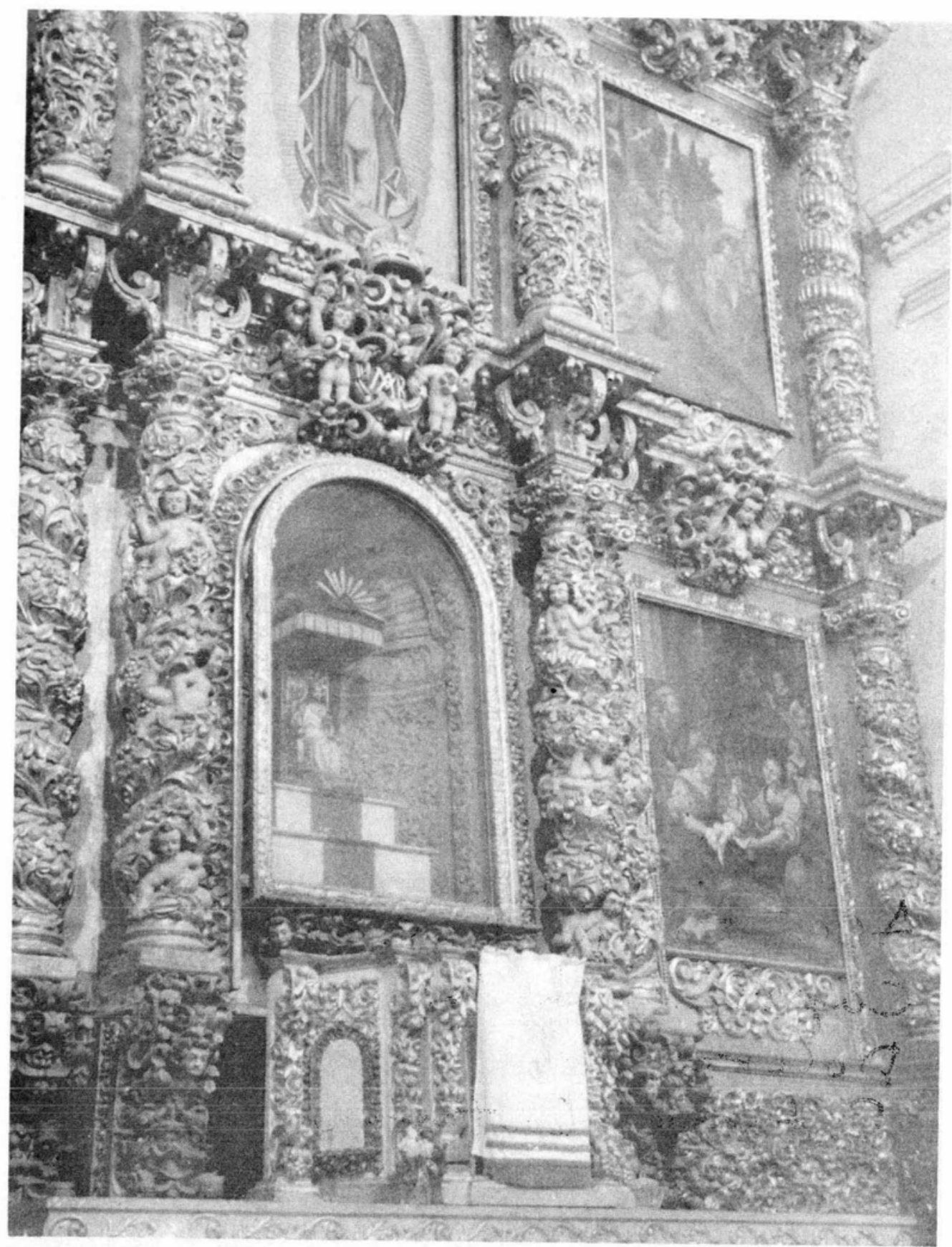

Lámina 8. Tlaxcala, Capilla de Guadalupe, detalle. 


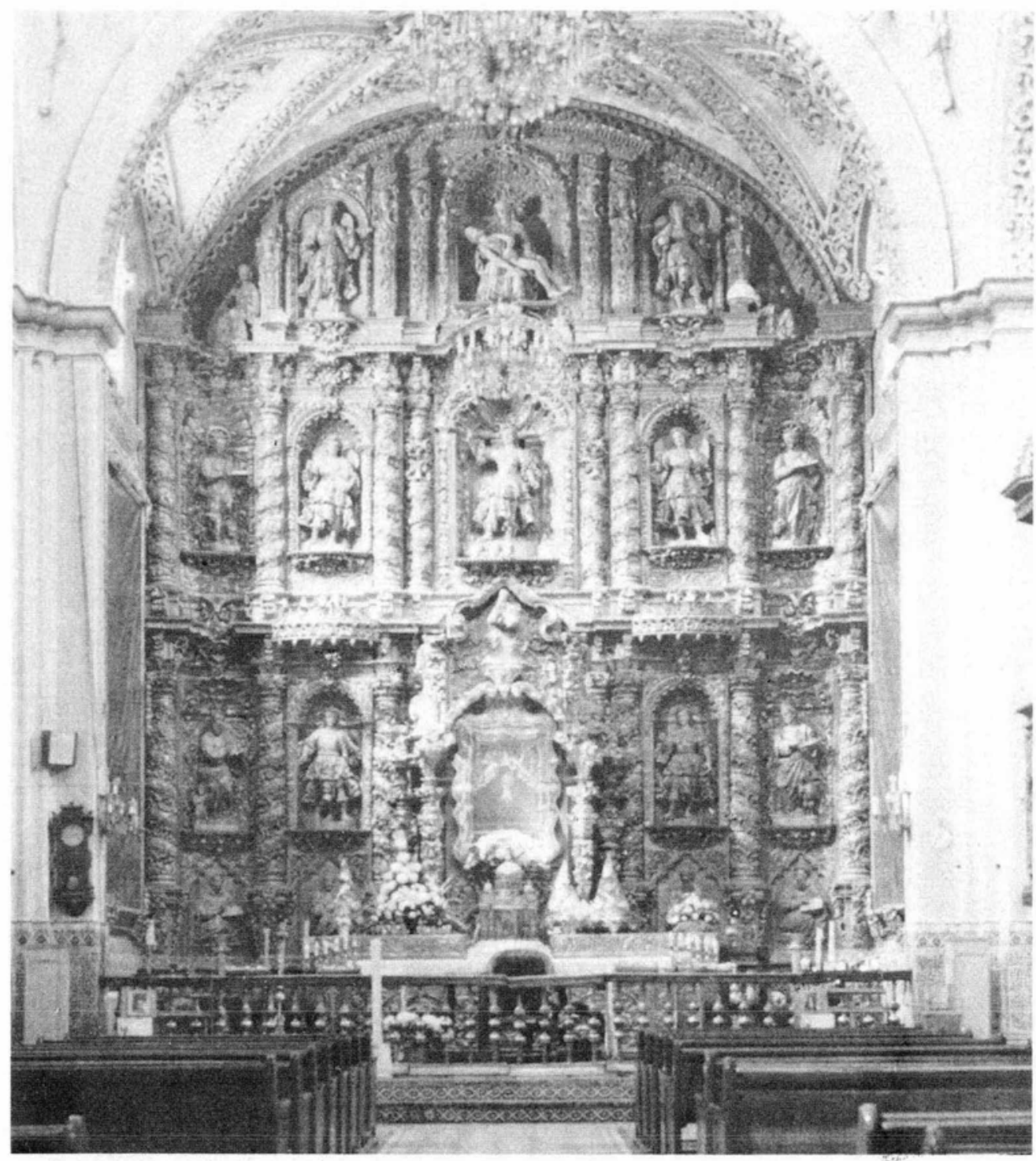

Lámina 9. Acatzingo. Capilla de los Dolores, retablo principal. 
DOI: http://dx.doi.org/10.22201/iie.18703062e.1982.50\%20Tomo\%201.1136

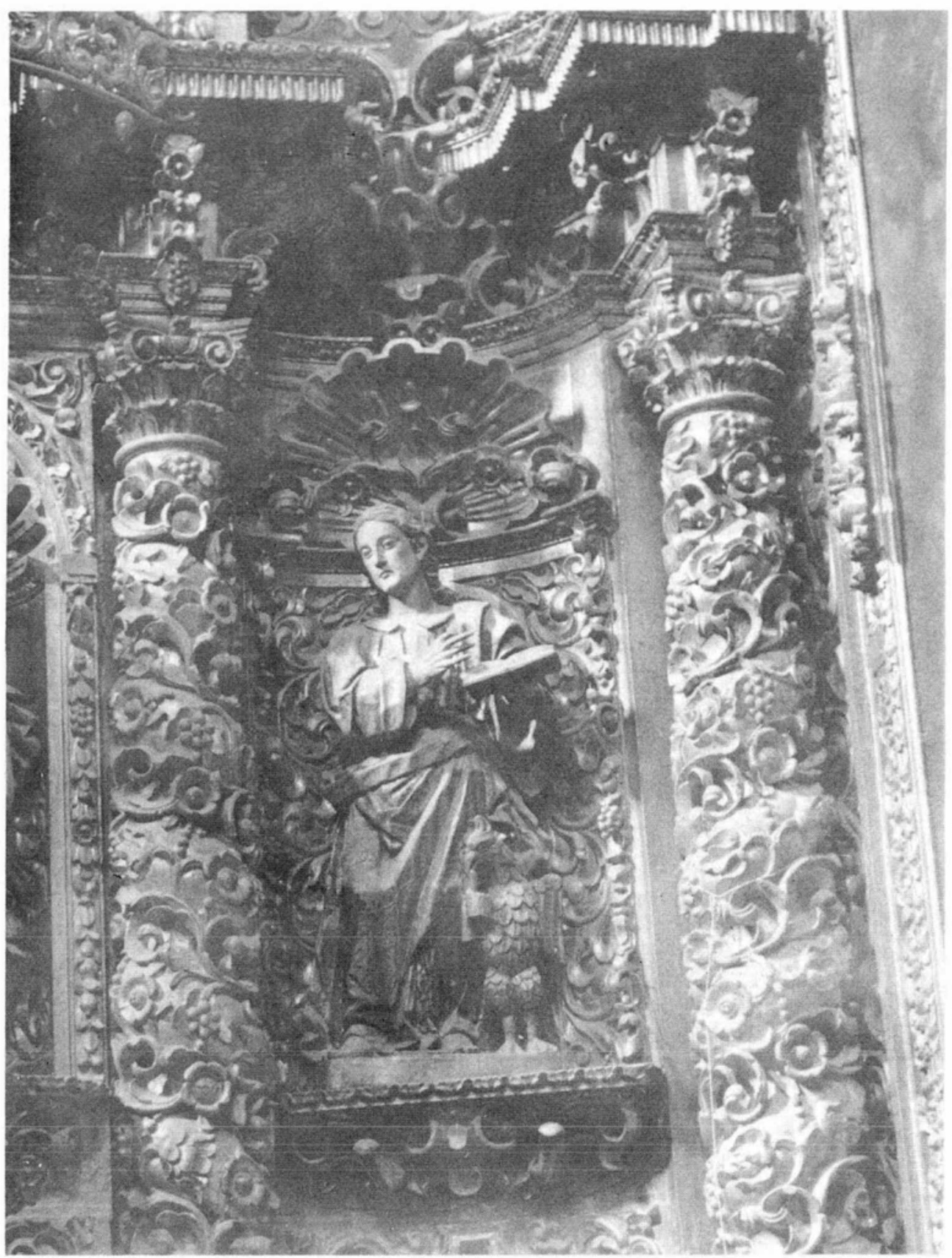

Lámina 10. Acatzingo. Detalle retablo principal. 
DOI: http://dx.doi.org/10.22201/iie.18703062e.1982.50\%20Tomo\%201.1136

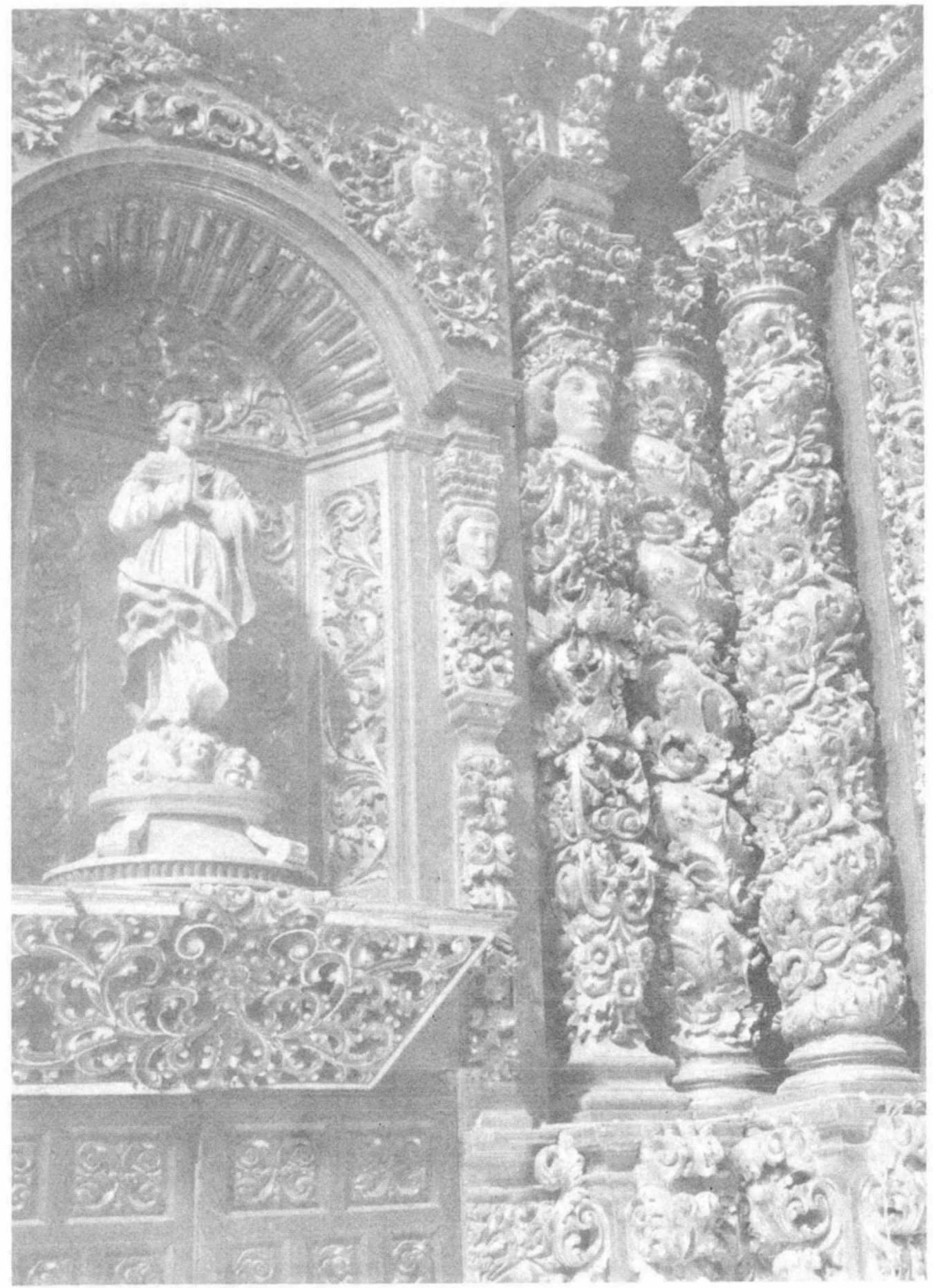

Lámina 11. Acatzingo. Retablo crucero. 


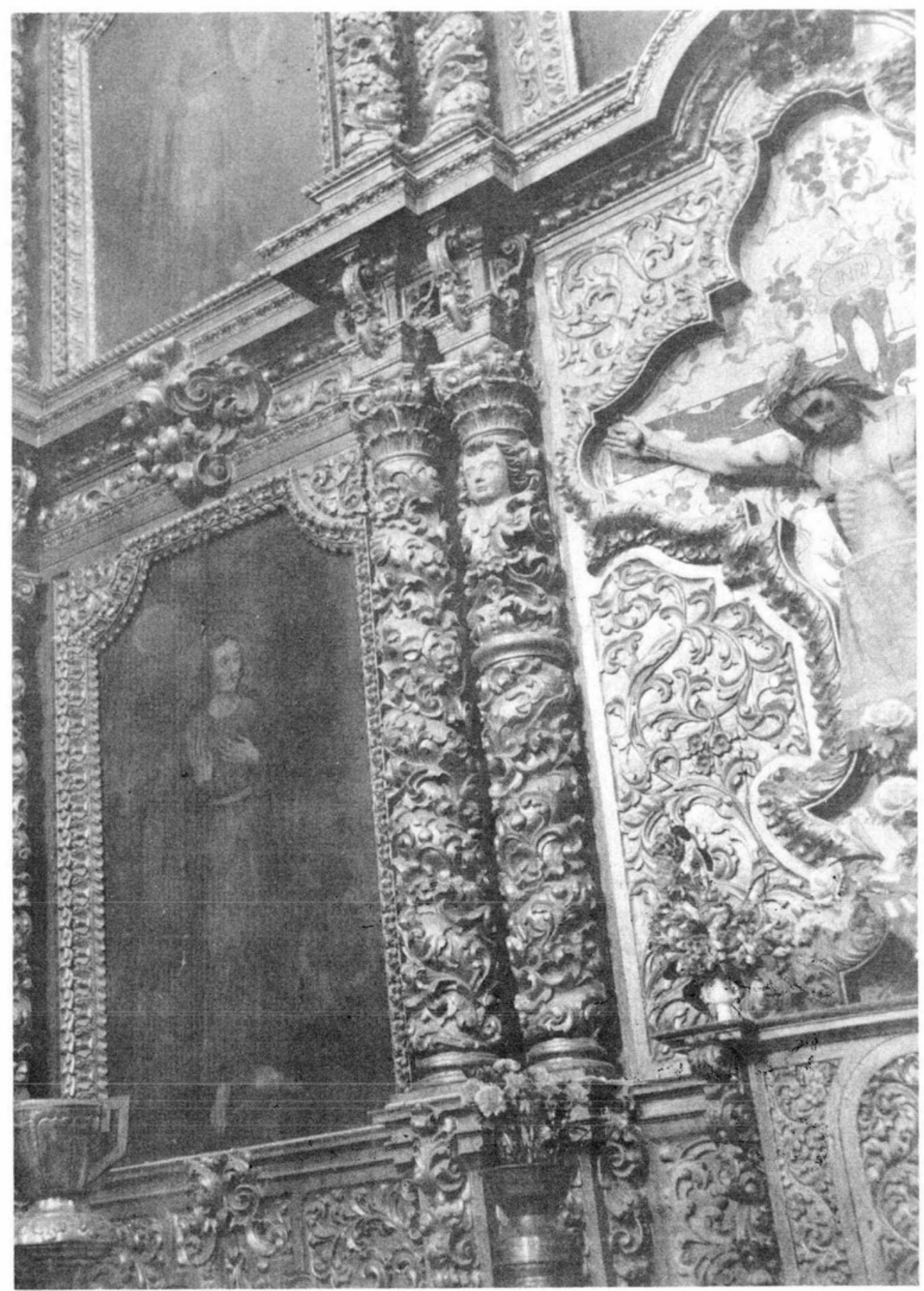

Lámina 12. Acatzingo. Capilla de los Dolores. Retablo lateral. 


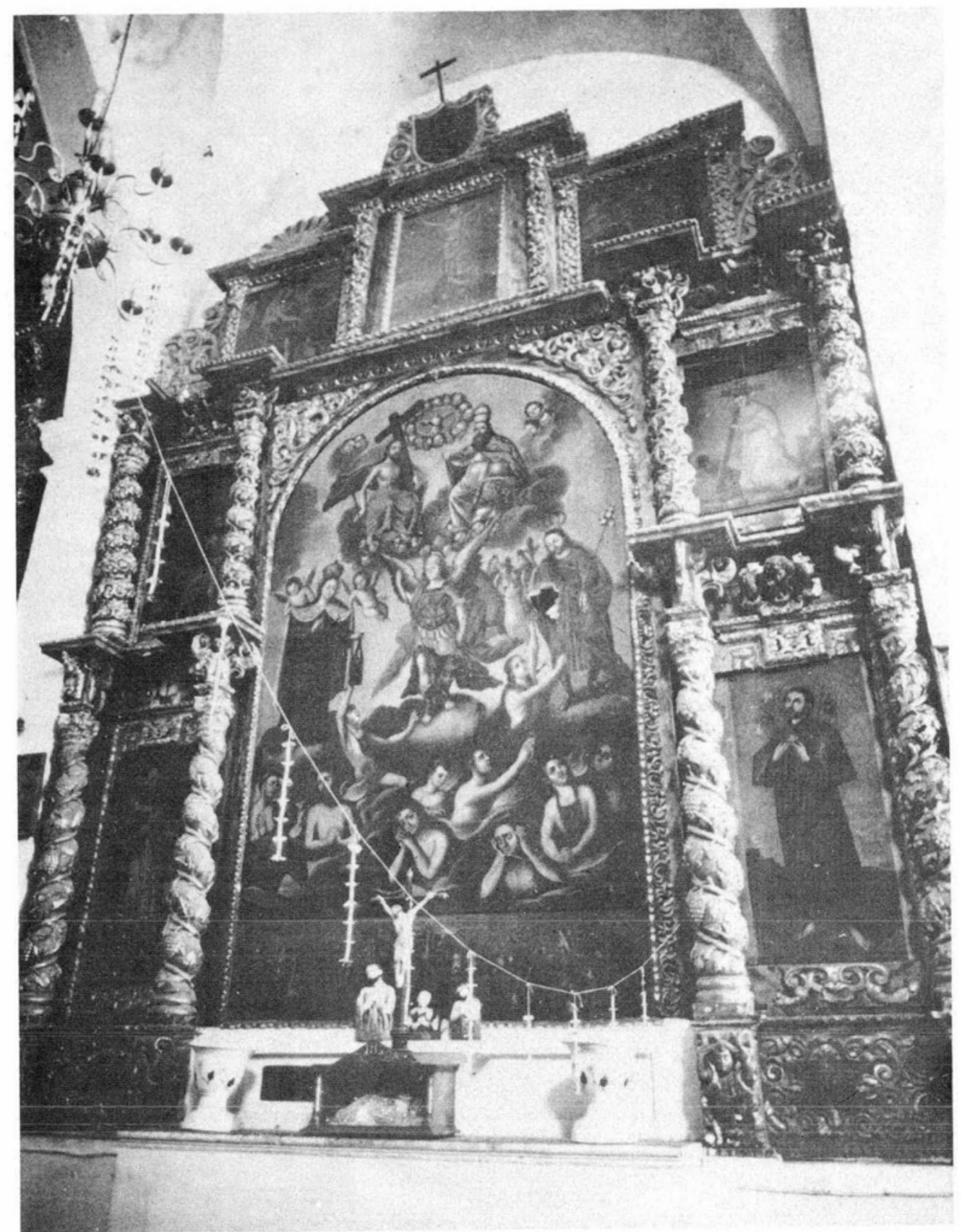

Lámina 13. Quecholac Pue. Retablo lateral. 
DOI: http://dx.doi.org/10.22201/iie.18703062e.1982.50\%20Tomo\%201.1136

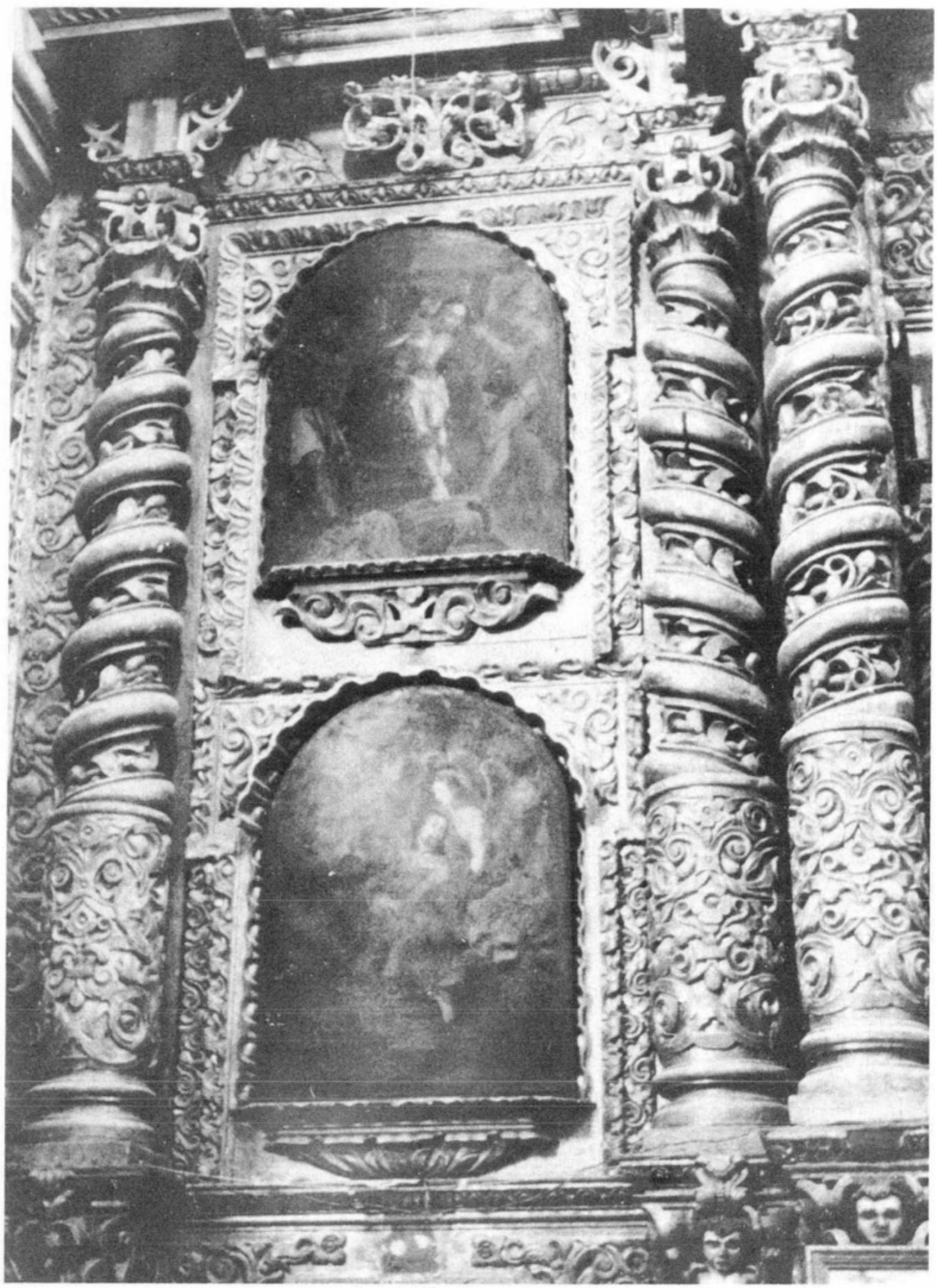

Lámina 14. Nopalucan Pue. Retablo lateral, detalle. 


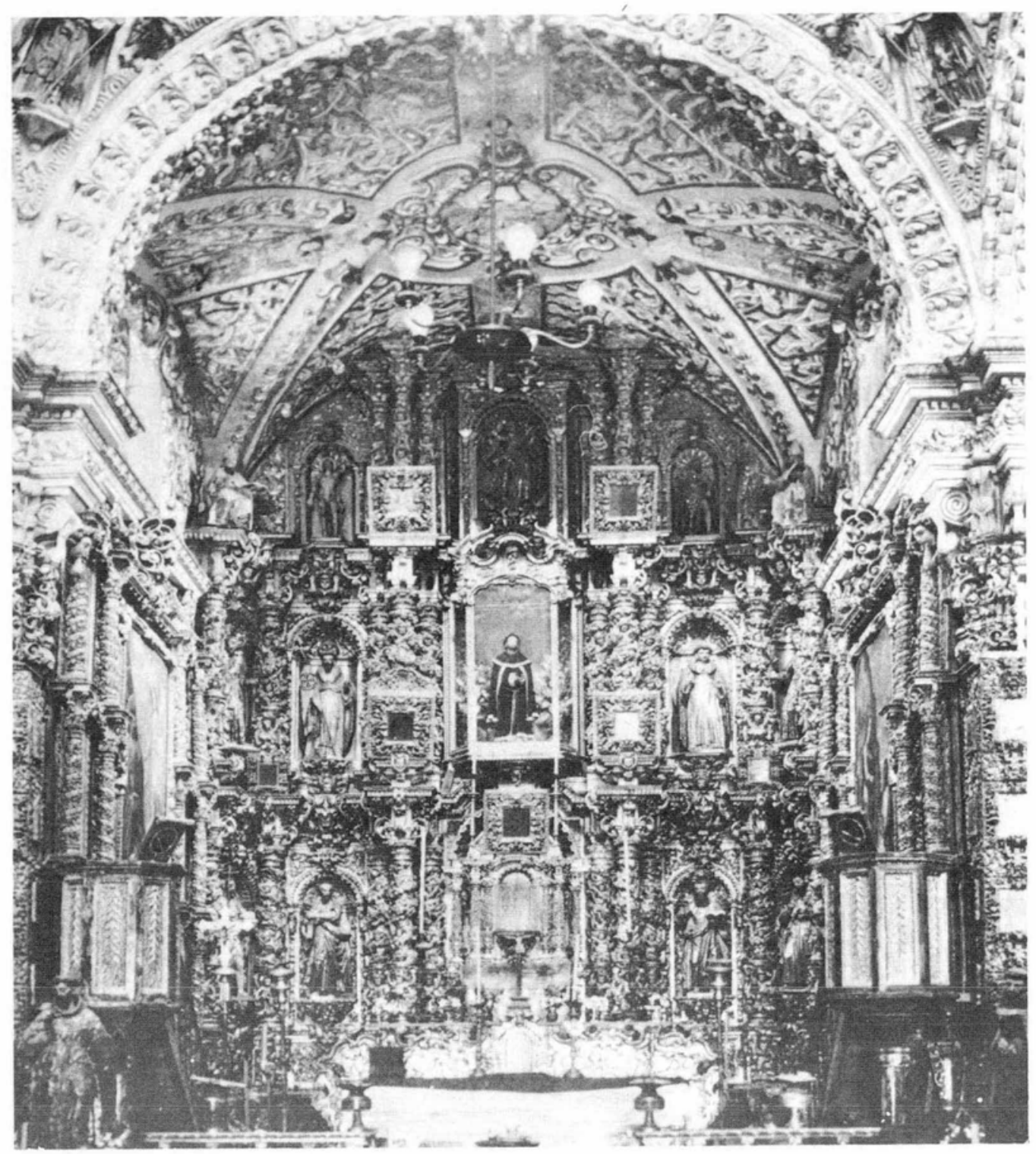

Lámina 15. San Francisco Acatepec. Retablo principal desaparecido. Foto Luis Márques. 
DOI: http://dx.doi.org/10.22201/iie.18703062e.1982.50\%20Tomo\%201.1136

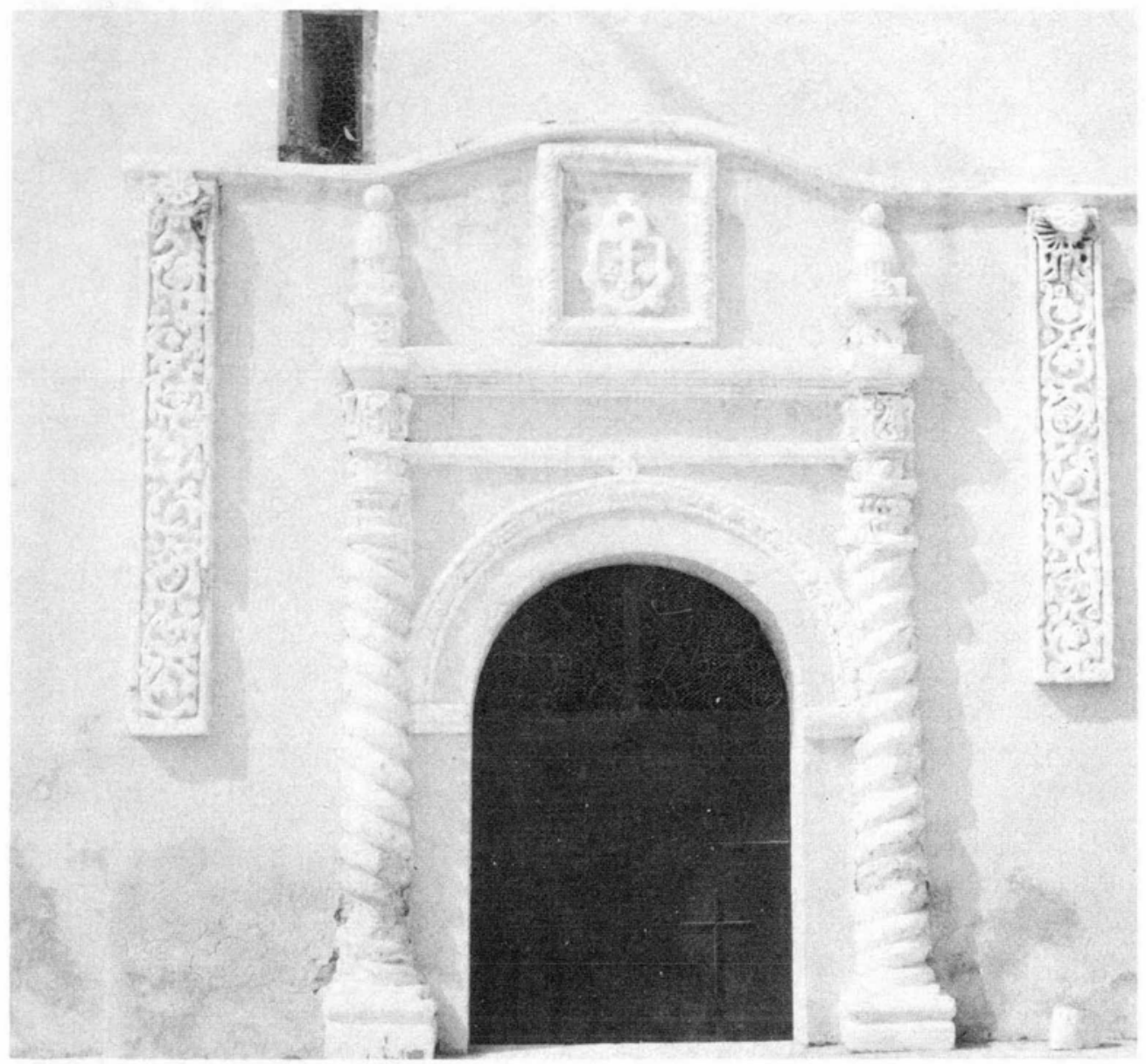

Lámina 16. Acatzingo. Portada lateral de la parroquia. 
detectamos en esta obra otros rasgos del salomónico. La cubierta del altar es de ingenioso diseño dividida en gajos cada uno de los cuales se orna con roleos, el cupulín adopta el mismo criterio de libertad.

Pese a su indudable importancia como obra artística, este altar no parece tener consecuencias, en cambio los retablos ejecutados en madera que consignamos enseguida si tienen conexión con nuestra área de estudio

El retablo de la parroquia de San José de la ciudad de puebla localizado en la nave lateral izquierda, está muy alterado, su estructura se condiciona por el espacio destinado a la imagen titular y un rasgo muy definido de la modalidad es la manera de agrupar los soportes de la calle central duplicándolos.

La iglesia monjl de Santa Catarina conserva dos retablos, los elementos rocoizantes que completan las sencillas estructuras parecen indicar que son bastante tardios, sin embargo los soportes son muestra de posibilidades expresivas cuya relación con nuestra área de estudio se antoja más coherente, son de especial interés los fustes tristostilos divididos y estriados totalmente en la zona helicoidal

Los retablos de la Soledad también en la ciudad de Puebla pueden ser en fecha cercana a la dedicación de la iglesia $-1749{ }^{7}$ Localizados en los cruceros y gemelos en su estructura, sorprende en ellos una concepción tan fragmentada Como una característica en plena evolución debe considerarse el reforzamiento de la estructura en la parte central, el uso de líneas quebradas en los elementos de cerrazón y el tratamiento dado a los soportes que señalan su primer tercio con una temática diferenciada. Es interesante consignar la presencia de soportes antropomorfos que habrian de alcanzar gran desarrollo en el área objeto de este análisis. Los elementos decorativos complementarios son de gran riqueza y muy sorpresivo es el hecho de que la escultura se subordine exclusivamente al primer cuerpo.

La difusión que en los diversos momentos debió alcanzar la modalidad salomónica, no tanto en su punto de arranque sino en el siglo XVIII, se puede encontrar en varios sitios que para aquellos años dependian en lo económico y espiritual de la ciudad de los Angeles.

El convento Franciscano de Tlaxcala conserva un interesante grupo de retablos que se pueden datar desde mediados del siglo XVII hasta el último cuarto del siglo XVIII. El principal del templo ha sido considerado como una obra de la centuria anterior a la cual se sustituyeron los soportes. Nosotros proponemos que tanto las pinturas como las esculturas y relieves fueron reutilizadas en una estructura que participa de grandes novedades en términos decorativos; las columnas salomónicas estriadas se ciñen con una guía vegetal. Los golpes de hojarasca y la decoración imbricada parecen antecedentes del coherente lenguaje que habria de significar el salomónico.

La capilla del tercer orden anexa a este recinto, fue construida hacia 1654 , el conjunto de retablos es posterior a esa fecha, proponemos una secuencia

$T$ Toussaint op. ( 11114 
para ellos, El del lado izquierdo dedicado a exaltar a los miembros de la tercera orden parece el más antiguo. Estructuralmente presenta la novedad de duplicar los soportes en la calle central donde se unen a los lenguajes en boga: columnas que no alteran su perfil cuyas bandas decorativas se colocaron en ángulo muy agudo. En el sotabanco se advierten tarjas muy planas mientras en las bases aparecen angelillos y los frisos se decoran con un tono arcaizante.

En el crucero opuesto el altar dedicado a Jesús de Nazareno tiene incorporados cuadros fechados en 1700 . En los dos registros se adoptan correctas columnas salomónicas, la calle central se subraya con la proyección de los nichos y los entablamentos se interrumpen con golpes de hojarasca. Un rasgo derivado de los tratados de preceptiva es el uso de las aletas que unen el remate aunque esas aletas se transforman con líneas ondulantes.

El retablo principal de la capilla parece obra más avanzada. De tranquila concepción en todas sus calles y aún en el remate se adopta la columna calada, el entablamento se amplifica y se da gran proyección a los resaltos, las calles laterales conservan la horizontalidad mientras en la calle central se eleva en suaves curvas. En el retablo predomina la escultura, ésta presenta rasgos de hieratismo y disposición simétrica, la expresión acusa efectividad y la policromía de los ropajes es de gran elaboración

La mayor parte de la capilla de los terciarios de Tlaxcala se recubre con otro tipo de retablos de dimensiones menores todos presentan rasgos variados que contribuyen a la unidad.

El retablo de San Antonio en la capilla lateral izquierda en Tlaxcala se puede datar en 1717 por los lienzos de autor anónimo, es una obra de original estructura condicionada por la variación de dimensiones de las pinturas donde se narra la vida del titular y la anómala presencia de dos efigies compartiendo la zona de honor de la parte central media. Las columnas en los dos niveles varían de diseño, las del registro bajo adosan vegetales de amplio trazo mientras en el cuerpo medio alternan en los senos una guía vegetal La decoración complementaria acusa un tono de libertad y otros motivos como la ménsulas y los modillones producen unạ obra cuyo carácter popular no se encuentra con frecuencia en esta zona

En la capilla de Guadalupe del templo tlaxcalteca encontramos otro retablo de gran interés. Dispuesto con sentido reticular, el entallador puso gran acento en la calle central con la duplicación de las columnas y su proyección. En este ejemplo hay una considerable variación en el tratamiento de los soportes, los del primer cuerpo incorporan niños desnudos en las ondulaciones del fuste. Los del registro alto son rectos en su primer tercio y la parte alta helicoidal se decora con incisiones y guías vegetales, en el remate se advierten pilastras con rostros humanos, la decoración vegetal complementaria es jugosa y entre los golpes de hojarasca se advierten torsos de niños que arrancan vides y granadas.

La capilla de la Virgen de los Dolores anexa a la parroquia de Acatzingo fue 
decorada entre 1750 y $1775^{\circ}$ Los retablos de los cruceros gemelos en diseño son de composición muy apaisada, los soportes son predominantemente salomónicos auque en la calle central aparecen las cariátides asociadas al mismo tipo de soportes helicoidales, los entablamentos siguen una trayectoria muy recta. La decoración complementaria es plana y agregada.

En el caso del retablo del crucificado - lado izquierdo - el perfil con que se señala su lugar es de gran belleza.

En el retablo del lado opuesto - derecho- dedicado al Ecce Homo también se observa el mismo criterio de composición aún cuando los soportes centrales en vez de ser helicoidales ostentan un agudo perfil que recuerda el estípite y se detecta cierta variación en los motivos decorativos especialmente en el asociado a la imagen central.

Toda la zona del crucero se unifica con pequeños retablos que utilizan el soporte salomónico y la columna hermes.

El retablo mayor de esta capilla muestra una estructura reticular y una gran comprensión del valor del volumen. Dispuesto sobre un banco abombado en cuya predella se dejan ver enmarcados por líneas mixtas cuatro santos escritores. La estructura se anima con la duplicación de los soportes en la parte central, zona donde los nichos son de forma variada. El fanal de la imagen titular es francamente rococó y debe corresponder a otra época. Flanquean esta zona soportes antropomorfos gemelos en diseño a los del retablo del crucifijo, la ocupación de las entrecalles con nichos, que adquieren variación de formas tanto en las peanas como en las veneras, es total. En el remate destacan pilastras con rostros y la orla que enmarca el retablo formado por curvas donde se incrustan ovas es idéntica a la de los colaterales

La escultura asociada a este magnífico retablo es de proporciones muy alejadas de los cánones clásicos, las posturas son elegantes, las manos acusan expresividad aún cuando hay sequedad en los gestos Es notable el tratamiento dado a los ropajes que parecen quebrarse en múltiples aristas.

La iconografía basada en la presencia de una Piedad que ocupa el sitio de honor y la custodia que ejercen los siete arcángeles, se completa con la presencia de los cuatro evangelistas que ilustran la necesidad de apoyo al culto de la imagen.

El poblado de San Juan de los Llanos - ahora conocido como Libres- conserva un buen conjunto de retablos. En los muros laterales de la parroquia hay un verdadero muestrario del salomónico, salvo en uno, en todos se evidencia la presencia de cariátides en el remate o zona más elevada.

El más coherente como estilo, además del mayor, es el inmediato al crucero quizá advocado a las ánimas del purgatorio que aparecen en el banco y bases de los soportes. El retablo datado en 1737 adopta una organización reticular, los nichos colocados en una composición tringular alternan con lienzos de

${ }^{8}$ La primera fecha la dan los lienzos firmados por Gaspar Muñóz, flanquean el retablo principal micntras la segunda fecha corresponde a los lienzos del cuerpo de la nave. 
perfil curvo. Aun cuando no parece haber una comprensión del sentido escultórico, la proyección de las cornisas y el fanal son logros indudables. La calle central se subraya con la presencia de los soportes antropomorfos en los cuales el fuste helicoidal llega hasta dos tercios y los torsos realistas y policromados elevan un brazo para tocar el capitel, los de los dos primeros cuerpos son huecos y con alusión eucarística y los de los extremos son del mismo diseño en tanto los soportes de la parte alta son diferentes.

El retablo principal realizado en 1728 adquiere movilidad tanto en las calles extremas como por la colocación de los soportes ${ }^{9}$ La multiplicación de los planos de fondo y la ocupación de las entrecalles por nichos de variada forma, todo elevado de una base decorada con salientes de hojarasca son las notas significativas.

El tratamiento de los soportes varía de cuerpo y los detalles como las ménsulas, golpes de hojarasca donde se incluyen nichos y molduras rizadas nos ilustran de un lenguaje común en toda la zona, el guardapolvo es anchísimo y recibió un tratamiento decorativo excepcional.

La proyección dada a las peanas y golpes de hojarasca nos hablan de la adopción de un lenguaje culto, la decoración vegetal aunque aplicada adquiere jugosidad y otros detalles como la cornisa rizada son reveladores de una mano de obra calificada.

En términos escultóricos encontramos que las representaciones de la predela son esquemáticas los apóstoles de gestos duros y posiciones afectadas en cambio la virgen quien se hace acompañar de sus parientes y los dos apóstoles fueron tratados en una reducción de volumen. La imagen del salvador del mundo es de gran interés. El resto de la escultura presenta intención de alargamiento y movilidad, los cuerpos se arquean y en la policromia predominan los azules grisácesos y el color azafrán.

Huamantla -en el actual estado de Tlaxcala - conserva en el cuerpo de la nave de su parroquia dos ejemplos de retablos salomónicos. El de la derecha dedicado a la Purísima presenta una solución muy fragmentada motivada por la presencia de múltiples imágenes devocionales. A pesar de esa fragmentación es notable la importancia concedida a la calle central subrayada por los nichos que adosan en sus pilastras rostros humanos. Las cornisas quebradas y el uso de golpes de hojarasca dan un valor peculiar a esta obra.

El retablo del lado opuesto dedicado al nazareno cuya imagen se advierte en el nicho bajo y cuya historia se recuerda en lienzo de perfil mixto, se significa por unas columnas muy proyectadas y por la presencia de cariátides, los fustes acuden a un expediente decorativo a base de estrías y a pesar de que la comprensión del lenguaje es limitada la obra es de interés.

En el viejo templo conventual de Quecholac, convertido en parroquia, se conservan varios ejemplos de retablos en los cuales el salomónico alcanza de-

\footnotetext{
9 Maria Antonieta Medina La iglesia y convento de Sanla María Magdalena de Quecholac. México, 1979-tesis 110
} 
sarrollada expresión. Un trabajo reciente nos permite inferir sus particularidades y establecer relación con otras obras ${ }^{10}$

El retablo dedicado a las ánimas del purgatorio construido posiblemente en 1780 y quizá proveniente del templo de los mercedarios de esa misma población guarda una estrecha relación con el retablo de los Reyes de la catedral de Puebla. Por la existencia de un gran lienzo, por la ausencia del sentido escultórico y por ciertas reminiscencias del pasado como la tarja donde se registra la inscripción de terminación del retablo. " Los soportes de espléndida realización enredan en sus senos vides alusivas a la eucaristía y los capitales son compuestos, en los resaltos de los soportes se adosan ménsulas y entre los golpes de hojarasca asoman rostros infantiles

Además de otro retablo de composición reticular datado en 1817 en el cual las notas singulares son la variación en el tratamiento de los nichos y las evolucionadas formas vegetales también, es de gran interés en esa obra la de persistencia de las ménsulas dispuestas sobre los soportes y las cornisas rizadas.

Un singular retablo es el localizado en el segundo tramo de este templo su advocación es incierta mas le da singularidad el uso de elementos novedosos y el hecho de que esté acabado en el color natural de la madera

El retablo es revolucionario tanto en la variación de las proporciones de sus dos cuerpos como en la alteración de la calle central y la colocación esviajada de los soportes, hecho que condiciona la disposición de las bases y los entablamentos.

Los soportes sufren un drástico cambio, en el primer cuerpo el torso se minimiza y las formas vegetales adosadas a los senos y gargantas adquieren un gran desarrollo. En el segundo cuerpo el criterio es similar, más las cariátides colocan una mano en el tocado y otra en la cadera. Los atlantes niños del remate se envuelven en follajes. Como persistencia del salomónico ejecutado en madera encontramos las ménsulas adosadas al entablamento, ellas adquieren tal trabazón con el capitel y volumen que aparecen tocados carnavalescos.

El retablo de San José Chiapa datado en 1769 por Francisco de la Maza, es por el uso del alabastro un homenaje a Juan de Palafox introductor de la modalidad en América ${ }^{12}$

En términos formales el retablo se desconecta de la secuencia por nosotros establecida y más bien propone una alternativa para el barroco que para aquellos años se encontraba en una posición crítica. ${ }^{13}$

Cabe ahora preguntarnos el sentido que tiene una exposición de la evolución del salomónico en Puebla toda vez que el estudio está incompleto, faltaría

10 La autor a antes citada realiza un cuidadoso catálogo de las obras r etablísticas de este sitio y nos informa que el retablo fue terminado bajo la mayordomia de Antonio Espíndola

"La lectura de la fecha de 1780 en un lienzo coincide vagamente con la cifra repintada, lo tardio de la obra no debe sorprendernos toda vez que hay retablos salomónicos en pleno siglo XIX

12 Francisco de la Maza San José Chupa México, INAH, 1960, p 51

13 La ultima categoría propuesta para el barroco por Jorge Alberto Manrique se discute en "El neostilo la última carta del barroco Mexicano" Hewma Hevana 1X, 3 México, 1971 
incorporar referencias formales a otros puntos del virreinato donde se desarrolló esta modalidad y aun considerando el esquema para el desarrollo de la modalidad en la ciudad es parcial.

Lo primero que salta a la vista es el escaso influjo que tuvieron las obras de la catedral hecho del cual se deriva la importancia y singularidad que tuvo la retablística ejecutada en madera.

En esta modalidad se percibe como constante la utilización de una composición reticular distinta a la acentuada fragmentación ejemplificada en los retablos de la Soledad y Huamantla. La liga entre esas dos posibilidades la establece el hecho de subrayar la calle central con muy diversos recursos entre los cuales, sin embargo, se advierte el predominio de soportes con elementos antropomorfos

La variación detectada en el tratamiento de la columna nos incita a conformar un catálogo de los soportes como el realizado para la provincia de Quito, sin embargo, ese catálogo para nuestras necesidades específicas deberá estar acompañado de consideraciones sobre las composiciones y apreciaciones más precisas sobre los elementos decorativos complementarios. ${ }^{14}$

Una vez realizada esta tarea deberá determinarse el influjo de los logros escultóricos en la arquitectura exterior que en apariencia es mínimo Para referirnos sólo a nuestra área encontramos escaso eco en la ciudad de Puebla. Sólo la capilla de Loreto presenta ese tipo de soportes y en la zona oriental del territorio detectamos en Acatzingo una portadilla y torres estructuradas con esos recursos tectónicos, cerca de ahí en la portada de San Hipólito se encuentra otro ejemplo de similar sencillez.

Esto nos lleva a concluir que el desarrollo de la modalidad arquitectónica del retablo salomónico en Puebla sigue caminos independientes como lo prueban las obras de Atlixco y el desaparecido retablo de San Francisco Acatepec Sin embargo, nos deja sugerencias y plantea la necesidad de un auxilio de carácter documental que clarifique si la fuerza de la tradición limitó las creaciones plásticas de Puebla y de todo el virreinato novohispano o si hay en el proceso elementos que sufrieron un desarrollo particular debido a sus creadores: los artífices mexicanos

14 F Samaniego Salazar Columna río quiteño: tres siglos de barroco decorativo Quito, Comisión de Valores, 1972 